Abstracted/indexed in Academic Search Complete, Asia Journals Online, Bangladesh Journals Online, Biological Abstracts, BIOSIS Previews, CAB Abstracts, Current Abstracts, Directory of Open Access Journals, EMBASE/Excerpta Medica, Google Scholar, HINARI (WHO), International Pharmaceutical Abstracts, Open J-gate, Science Citation Index Expanded, SCOPUS and Social Sciences Citation Index;

\title{
Efficacy of daclatasvir plus peginterferon alfa and ribavirin for patients with chronic hepatitis C genotype 4 infection
}

\author{
Hussien Ahmed', Abdelrahman Ibrahim Abushouk², Mohamed Gadelkarim, \\ Arwa Mohamed', Mohamed Gabr' ${ }^{1}$ and Ahmed Negida'
}

${ }^{1}$ Faculty of Medicine, Zagazig University, El-Sharkia, Egypt; ${ }^{2}$ Faculty of Medicine, Ain Shams University, Cairo, Egypt; ${ }^{3}$ Faculty of Medicine, Alexandria University, Alexandria, Egypt.

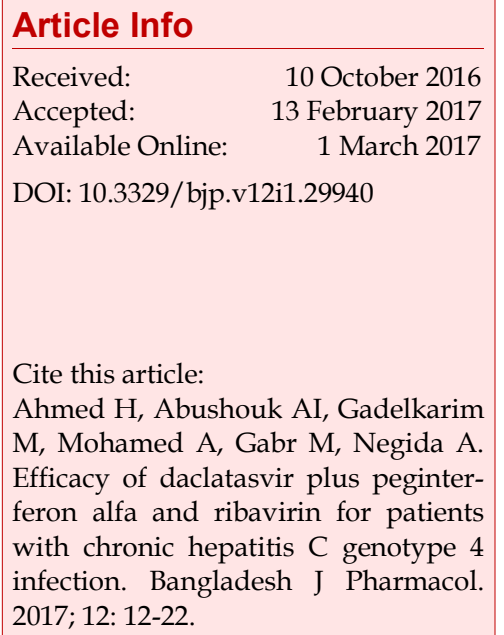

\begin{abstract}
Clinical trials evaluating the safety and efficacy of daclatasvir for chronic hepatitis $\mathrm{C}$ virus (HCV) genotype 4 infection are scarce and yet with small sample sizes. Therefore, we conducted this systematic review to investigate the efficacy of daclatasvir in HCV genotype 4 treatment. A computer literature search of PubMed, Scopus, Embase, Ovid, Web of knowledge, and Cochrane central was conducted. We selected studies comparing daclatasvir plus peginterferon-alfa/ribavirin versus placebo plus peginterferon-alfa/ ribavirin in patients with $\mathrm{HCV}$ genotype 4 infection. Pooling data from two randomized controlled trials $(\mathrm{n}=154$ patients) showed that daclatasvir/peginterferon/ribavirin treatment achieved a moderate sustained virologic response rate of $76 \%$ after 12 weeks and of $79 \%$ after 24 weeks. The daclatasvir containing regimen was superior to the placebo containing regimen in terms of virologic response rates after 12 weeks (RR=1.9\% CI 1.3 to 2.6) and 24 weeks (RR=1.8\% CI 1.3 to 2.5). More effective regimens are needed for HCV genotype 4 .
\end{abstract}

\section{Introduction}

Hepatitis $\mathrm{C}$ virus (HCV) infection is a globally prevalent disease that affects about 170 million individuals (Negro and Alberti, 2011). It is a major cause of liver cell failure and hepatocellular carcinoma, accounting for about 350,000 deaths annually (Armstrong et al., 2006; Hanafiah et al., 2013). Seven genotypes of HCV have been identified. Of them, genotype 1 is the most prevalent infection worldwide (Smith et al., 2014), while genotype 4 accounts for $20 \%$ of the global burden of $\mathrm{HCV}$ infection, with a high prevalence in the Middle East and Central and North Africa (Cornberg et al., 2011; Kamal, 2011). Multiple factors affect patients' response to antiviral therapy including viral genotype, viral load, host genetics, and patients' demographics (Ghany et al., 2009; Thompson et al., 2010).

Current treatment options for HCV genotype 4 include the NS5B polymerase inhibitor (sofosbuvir) or NS3 protease inhibitor (simeprevir) plus peginterferon-alfa and ribavirin (Peg-IFN/RBV) (Pawlotsky et al., 2015). However, the increased incidence of adverse events associated with interferon-based regimens triggered the development of interferon-free therapeutic combinations (Hézode et al., 2014). In vitro studies show that daclatasvir, an NS5A inhibitor, has a pan-genotypic activity with picomolar potency and pharmacokinetic characteristics allowing for single daily dosage regimens (Fridell et al., 2011; Wang et al., 2012). It acts via inhibiting the NS3 protease enzyme and therefore, preventing NS5A hyperphosphorylation, leading to inhibition of viral replication complex formation (Lee et al., 2011; Qiu et al., 2011).

Phase II clinical trials showed that the combination of daclatasvir (60 mg) with Peg-IFN/RBV exhibited more 
efficacy than Peg-IFN/RBV alone with a similar safety profile and allowed for a shorter treatment duration (Dore et al., 2015; Hezode et al., 2015). Moreover, addition of asunaprevir to the former regimen of daclatasvir plus Peg-IFN/RBV achieved a sustained virologic response rate (SVR) of $100 \%$ after 12 weeks of treatment (Jensen et al., 2015).

Although more than $90 \%$ of $\mathrm{HCV}$ infections in the Middle East and Africa are of genotype 4 (Karoney and Siika, 2013), studies assessing the efficacy of daclatasvir in patients with $\mathrm{HCV}$ genotype 4 are scarce and yet with small sample sizes. Therefore, we conducted this systematic review and meta-analysis to investigate the efficacy of daclatasvir in treating patients with $\mathrm{HCV}$ genotype 4 .

\section{Materials and Methods}

We followed the PRISMA statement guidelines during the preparation of this systematic review and metaanalysis (Moher, 2009).

\section{Criteria for selecting studies to this review}

We used the following inclusion criteria: a) Population: Cirrhotic or non-cirrhotic adult patients with chronic $\mathrm{HCV}$ genotype- 4 infection, b) Intervention: $20 \mathrm{mg}$ and/ or $60 \mathrm{mg}$ of daclatasvir plus Peg-IFN/RBV (triple regimen), c) Comparator: Placebo plus Peg-IFN/RBV (dual regimen), d) Efficacy outcomes: Measured in virologic response rates, and e) Study design: Randomized controlled trials. We excluded: a) Non-randomized trials, b) Studies comparing the efficacy of daclatasvir with other direct antiviral agents, c) In vitro and animal studies, d) Studies including patients, co-infected with Hepatitis B Virusor immunodeficiency virus, and e) Studies whose data were unreliable for analysis.

\section{Literature search strategy}

We searched PubMed, Scopus, Embase, Ovid, Web of knowledge, and Cochrane central through March, 2016 using relevant keywords (Daclatasvir OR BMS-790052 OR NS5A inhibitor). No language restrictions were imposed. We also manually searched the reference list of included studies for any missing citations.

\section{Screening of records}

Duplications between databases were removed and finally, retrieved references were screened for randomized controlled trials comparing daclatasvir plus PegIFN/RBV versus placebo plus Peg-IFN/RBV. References were screened in two steps: The first step was to screen titles/abstracts for eligibility and the second step was to screen full text articles of eligible abstracts.

\section{Data extraction}

Two independent authors (HA and AM) extracted data using an online data extraction form. Disagreements were resolved through discussion and consensus among the reviewers. The extracted data included the following domains: a) Characteristics of study design, b) Baseline criteria of included population and c) Study outcomes.

\section{Primary efficacy measure}

The efficacy of antiviral treatment was assessed by SVR and relapse rate. SVR is defined as patients with undetectable HCV RNA level at 12 or 24 weeks after cessation of treatment, while relapse rate is defined as detectable HCV RNA level during follow-up after achieving undetectable levels at any point of treatment.

\section{Secondary efficacy measures}

The secondary efficacy measures included: Rapid virologic response rate (RVR) [defined as undetectable HCV RNA at week 4 of treatment], extended rapid virological response (eRVR)[defined as HCV RNA <10$15 \mathrm{IU} / \mathrm{mL}$ at weeks 4 and 12 of treatment], complete early virological response (cEVR)[defined as $\geq 2$ $\log _{10}$ reduction from baseline HCV RNA and the virus is undetectable], and end of treatment response (EOTR) [defined as undetectable HCV RNA at the end of treatment] (Lindsay, 1997; Yu et al., 2007).

\section{Risk of bias assessment}

The risk of bias of the retrieved clinical trials was assessed according to the Cochrane handbook of systematic reviews of interventions 5.1.0 (updated March, 2011) by two independent reviewers. Any discrepancies between the two assessors were resolved through discussion with a third assessor.

\section{Data synthesis}

Study outcomes were pooled as a risk ratio (RR) in a fixed effect model meta-analysis using Mantel-Haenszel method. A subgroup analysis, according to daclatasvir dose, was conducted whenever possible. For all outcomes, effect estimates of the two doses (20 vs $60 \mathrm{mg}$ ) were compared by chi-square test. All analyses were conducted by Revman software version 5.3 for Windows.

\section{Assessment of heterogeneity}

Heterogeneity was assessed using the chi-square test and extent was measure using the I-square tests.

\section{Publication bias}

According to Egger and colleagues, the assessment of publication bias is not reliable for less than 10 pooled studies. Therefore, in the present study, we could not assess the existence of publication bias by Egger's test for funnel plot asymmetry (Egger et al., 1997; Terrin et al., 2003). 


\section{Results}

\section{Search results}

Our search retrieved 1,856 unique citations. Of them, 36 records were eligible for full text screening. Finally, 34 articles were excluded and two randomized controlled trials (with a total of $154 \mathrm{HCV}$ genotype 4 patients) were included in the final analysis (Figure 1).

\section{Risk of bias in included studies}

The risk of bias in included studies was low according to the Cochrane risk of bias assessment tool. The summary of risk of bias assessment domains and authors' judgments with justifications are shown in the supplementary data in page 22 .

Our analysis included 154 patients with HCV genotype 4 (daclatasvir: 106 patients and placebo: 48 patients). Baseline characteristics of each study population are shown in Table I and the summary of included studies and their main results are shown in Table II.

\section{Sustained virologic response rate (SVR)}

The daclatasvir plus Peg-IFN/RBV treatment achieved a SVR of $76 \%(81 / 106)$ after 12 weeks and $79 \%(84 / 106)$ after 24 weeks. Compared with the SVR rate in the placebo plus Peg-IFN/RBV group, the daclatasvir containing (triple) regimen was superior after 12 weeks $(\mathrm{RR}=1.9 \% \mathrm{CI}[1.3$ to 2.6], $\mathrm{p}=0.0002$; Figure 2A). Pooled studies were homogenous $\left(\mathrm{p}=0.87 ; \mathrm{I}^{2}=0 \%\right)$. The SVR after 24 weeks was also higher in the triple regimen group ( $R R=1.8 \% \mathrm{CI}$ [1.3 to 2.5], $\mathrm{p}=0.0002$; Figure $2 \mathrm{~B})$. Pooled studies were homogenous $\left(\mathrm{p}=0.45 ; \mathrm{I}^{2}=0 \%\right)$.

\section{Relapse rate}

The relapse rate was lower in the triple regimen group, compared to the dual regimen group $(\mathrm{RR}=0.2 \% \mathrm{CI}[0.1$ to 0.5$], p=0.002$; Figure $3 \mathrm{~A})$. Pooled studies were homogenous $\left(\mathrm{p}=0.032 ; \mathrm{I}^{2}=13 \%\right)$.

\section{Rapid virologic response rate (RVR)}

Daclatasvir plus Peg-IFN/RBV group was superior to placebo plus Peg-IFN/RBV group in terms of RVR $(\mathrm{RR}=6.6 \% \mathrm{CI}$ [3.1 to 14.2], $\mathrm{p}<0.0001$; Figure 3B). Pooled studies were homogenous $\left(\mathrm{p}=0.80 ; \mathrm{I}^{2}=0 \%\right)$.

\section{Extended rapid virologic response rate (eRVR)}

Daclatasvir plus Peg-IFN/RBV group was superior to placebo plus Peg-IFN/RBV group in terms of eRVR (RR=5.3\% CI [2.6 to 10.7], $p<0.0001$; Figure 4A). Pooled studies were homogenous $\left(\mathrm{p}=0.89 ; \mathrm{I}^{2}=0 \%\right)$.

\section{Complete early virologic response rate (cEVR)}

Daclatasvir plus Peg-IFN/RBV group was superior to placebo plus Peg-IFN/RBV group in terms of cRVR $(\mathrm{RR}=1.7 \% \mathrm{CI}$ [1.3 to 2.3], $\mathrm{p}=0.0002$; Figure $4 \mathrm{~B})$. Pooled studies were homogenous ( $\left.\mathrm{p}=0.81 ; \mathrm{I}^{2}=0 \%\right)$.

\section{End of treatment viral response (EOTR)}

Daclatasvir plus Peg-IFN/RBV group was superior to placebo plus Peg-IFN/RBV group in terms of EOTR

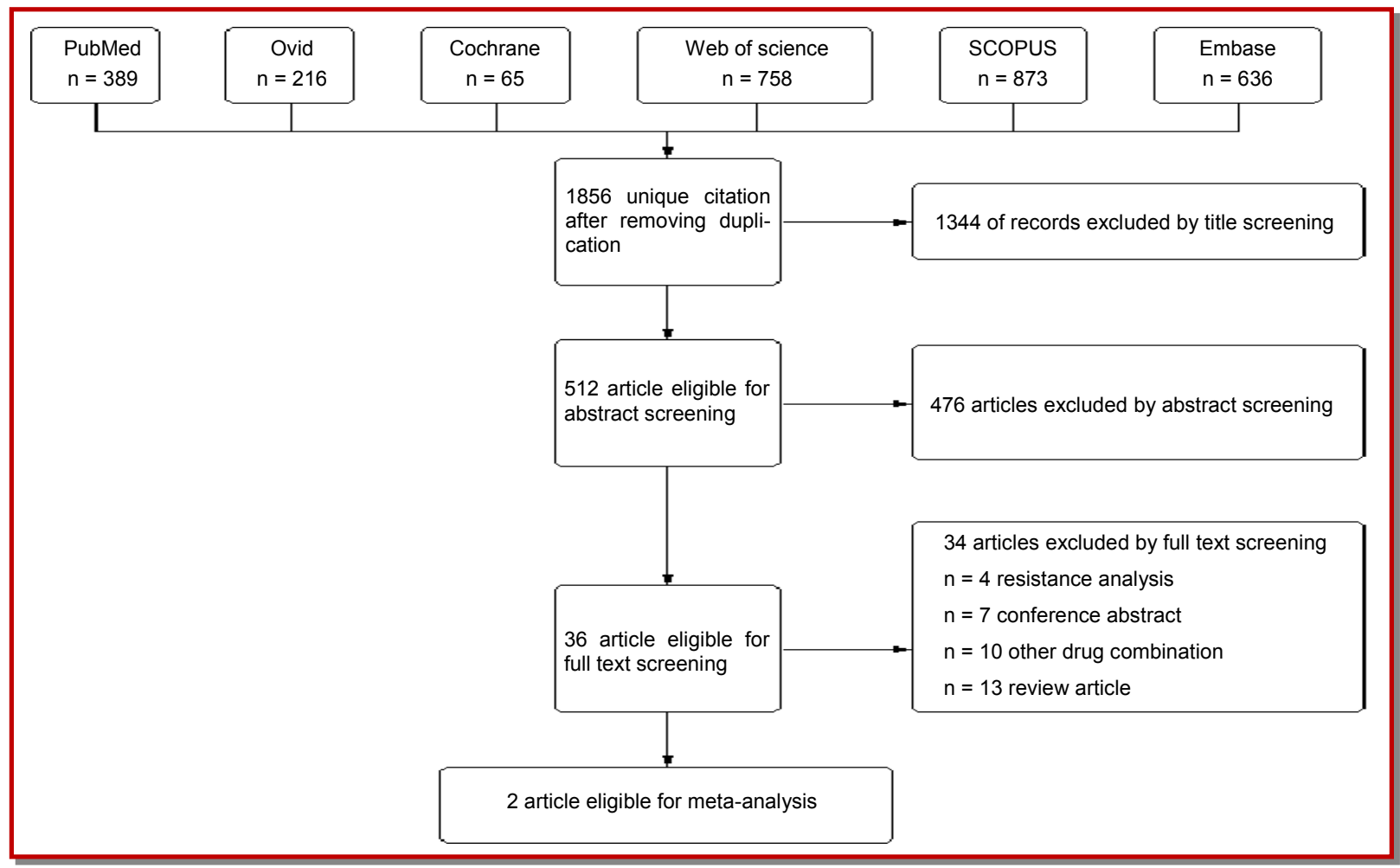

Figure 1: Flow diagram of search strategy and study selection 


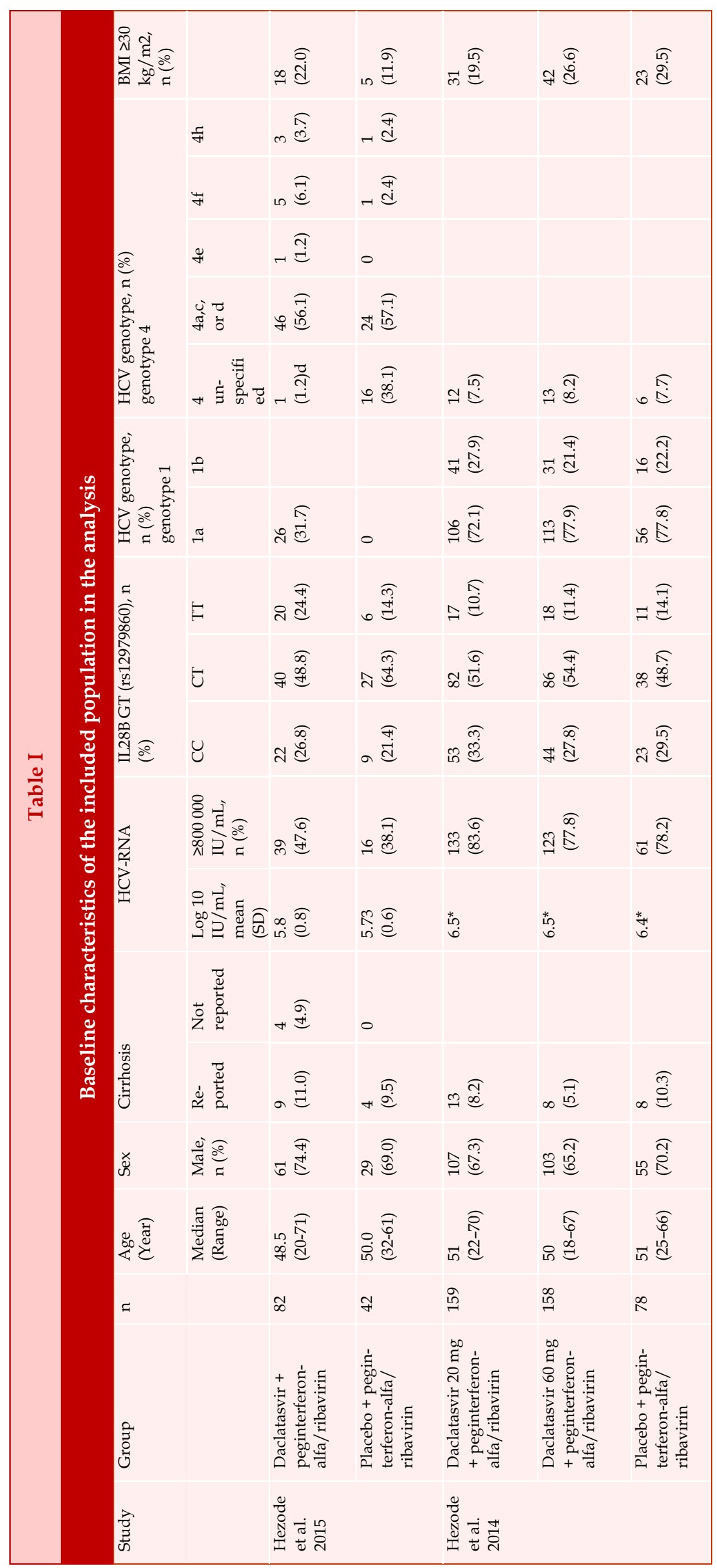




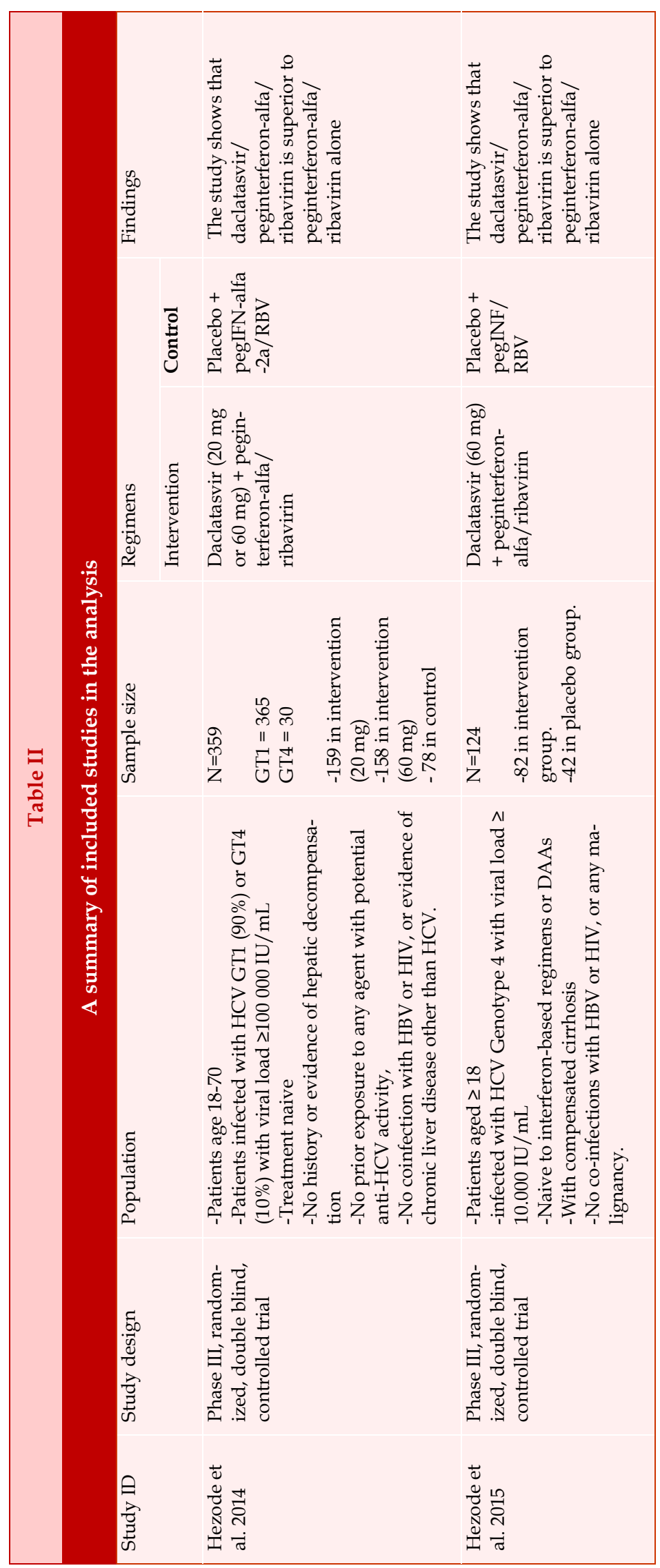




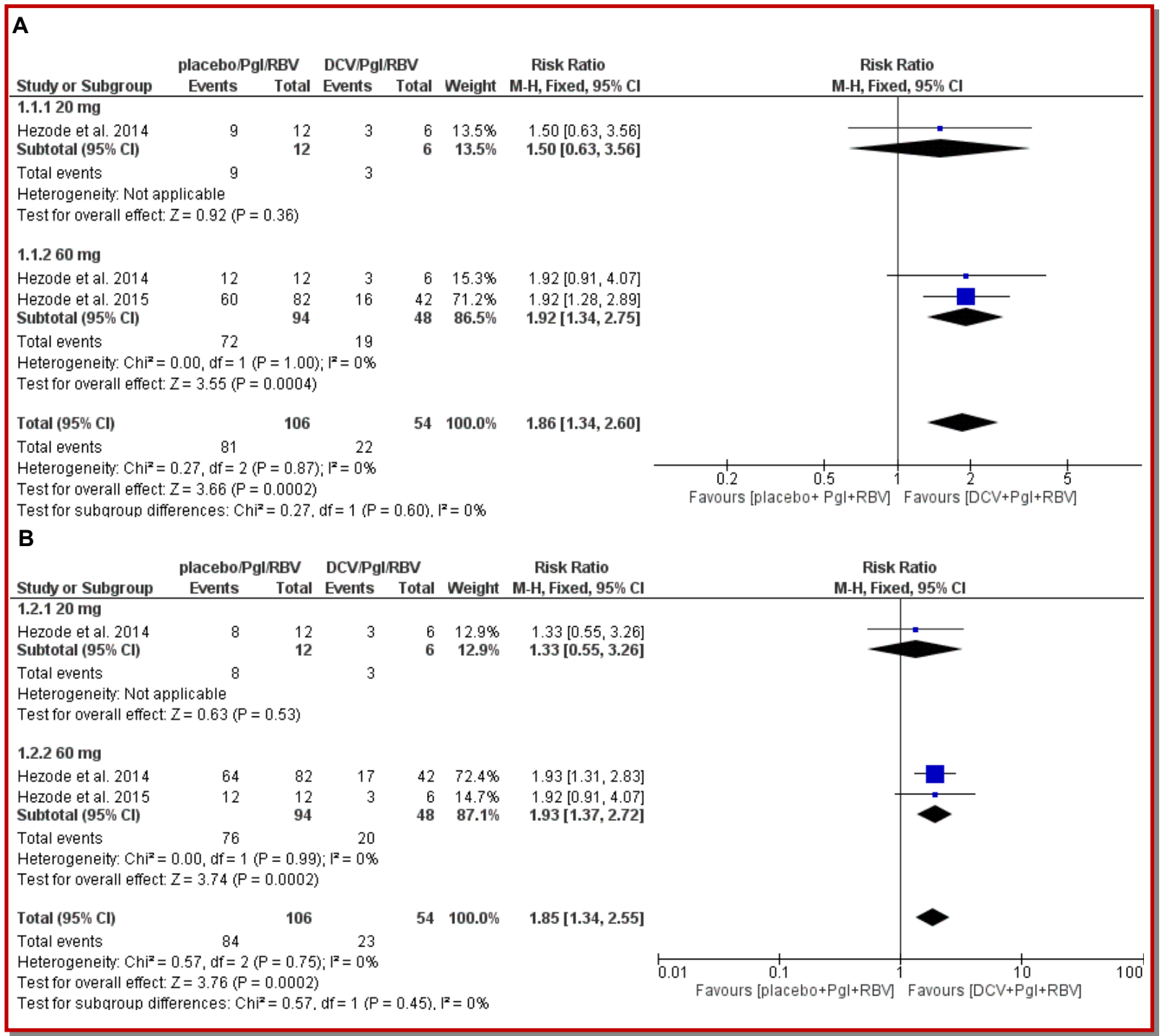

Figure 2: Forest plots comparing the dual and triple regimens in terms of SVR at 24 weeks (A) and 24 weeks (B)

(RR=1.7\% CI [1.3 to 2.2], $\mathrm{p}=0.0001)$. Pooled studies were homogenous $\left(\mathrm{p}=0.31 ; \mathrm{I}^{2}=3.9 \%\right)$.

\section{Daclatasvir dose $60 \mathrm{mg}$ vs $20 \mathrm{mg}$}

For all efficacy outcomes, data were presented in two subgroups according to the dose of daclatasvir $(60 \mathrm{mg}$ vs $20 \mathrm{mg}$ ). There was no statistically significant difference between the two doses in all efficacy outcomes (test for subgroup analysis: $\mathrm{p}>0.05$ ).

\section{Discussion}

\section{Summary of evidence}

This study provides class one evidence that daclatasvir plus Peg-IFN/RBV regimen achieves moderate efficacy in treatment of chronic HCV infection genotype 4 . The overall effect size of SVR, RVR, eRVR, cEVR, and EOTR rates was higher in the daclatasvir plus Peg-IFN/RBV compared to the placebo plus Peg-IFN/RBV group.

\section{Daclatasvir dose $20 \mathrm{mg}$ vs $60 \mathrm{mg}$}

Two doses of daclatasvir (20 and $60 \mathrm{mg}$ ) were investigated in included clinical trials and were pooled in our analysis. Our results showed that both doses achieved comparable SVR rates at 12 and 24 weeks (Hézode et al., 2014). However, it is expected that the $60 \mathrm{mg}$ dose might provide higher SVR rates in patients with insufficient response to other regimens such as patients with cirrhosis, those with an initially high viral load, and resistant polymorphism substitutions (Chan et al., 2012).

\section{Comparison to other regimens}

Although daclatasvir plus Peg-IFN/RBV regimen achieved higher SVR rates than the dual regimen, it showed moderate SVR rates of $76 \%$ after 12 weeks and $79 \%$ after 24 weeks. In a previous study, genotype 4 patients treated with a combination of sofosbuvir and 


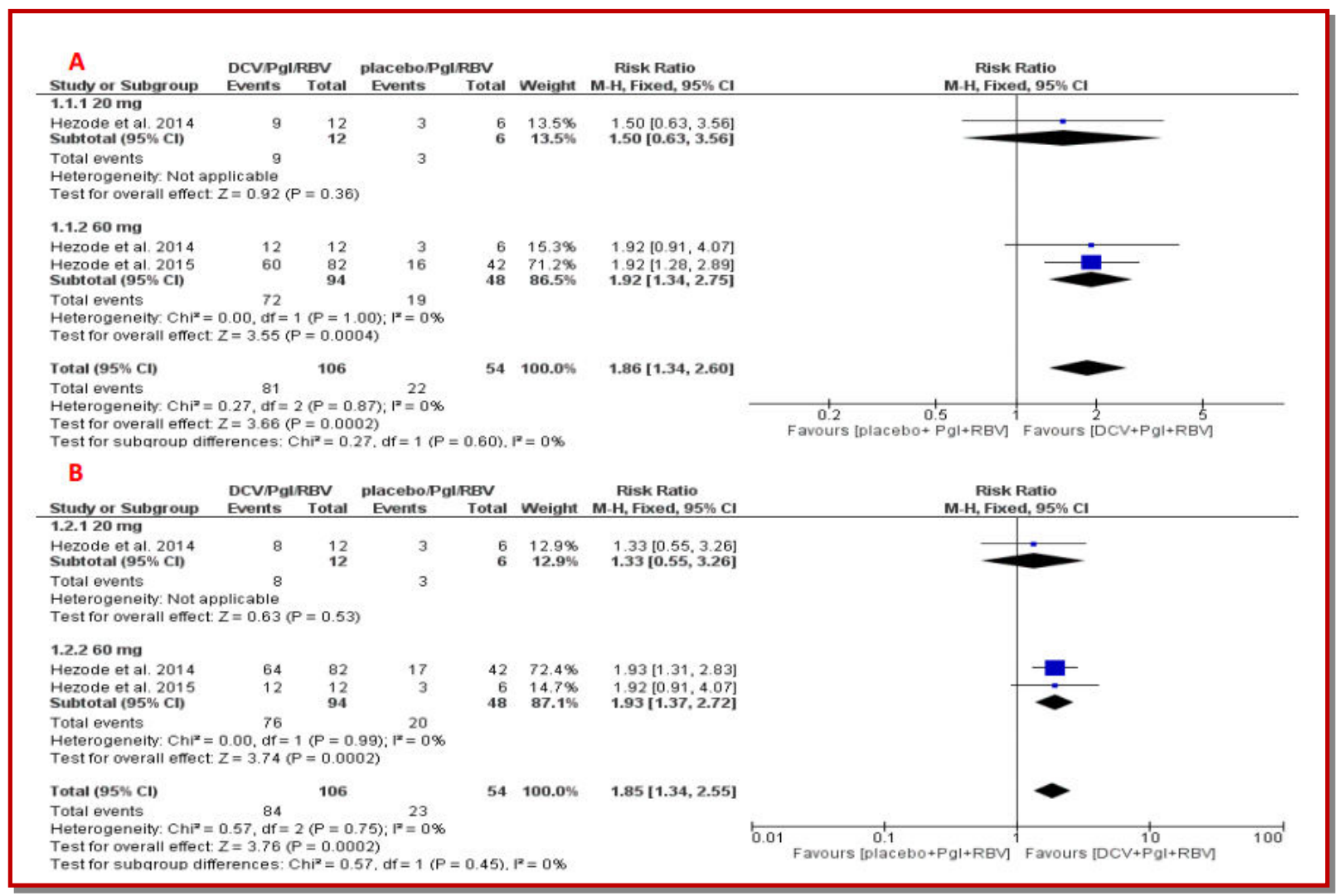

Figure 3: Forest plots comparing the dual and triple regimens in terms of relapse rate (A) and rapid virologic response rate (B)

Peg-IFN/RBV achieved a SVR rate of $96 \%$. In another study, genotype 4 patients treated with simeprevir plus Peg-IFN/RBV achieved a SVR rate of $83 \%$ (Lawitz et al., 2013; Moreno et al., 2014). In comparison to these regimens, the daclatasvir plus Peg-IFN/RBV regimen is not strongly recommended for treatment of $\mathrm{HCV}$ genotype 4 patients. However, the evidence is insufficient and further trials are required to investigate the efficacy of this regimen in HCV genotype 4 patients.

Recent data in the literature suggests that most oral combinations of direct antiviral agents provide high SVR rates with shorter treatment duration, excellent tolerability, and low rates of virological relapse. Fortunately, most of these combinations allow for an interferon-free treatment regimen and therefore, less complications (Everson et al., 2014; Hassanein et al., 2014; Kumada et al., 2014; Suzuki et al., 2013).

Combining daclatasvir with other direct antiviral agents such as asunaprevir, sofosbuvir or BMS-791325 have shown a high SVR-up to $100 \%$-in treatment naïve genotype 1 and 2 patients (Everson et al., 2014; Sulkowski et al., 2014). A recent meta-analysis has shown that combining daclatasvir and sofosbuvir achieved a SVR rate of $88.8 \%$ at 12 weeks in patients infected with genotype $3 \mathrm{HCV}$ (Swallow et al., 2015). Sofosbuvir plus daclatasvir combination has been recently approved in the US and EU for treatment of genotype 3 (Pawlotsky et al., 2015). Combining daclatasvir with asunaprevir plus Peg-IFN/RBV achieved a SVR of 100\% ingenotype 1 and 4 non-responders (Jensen et al., 2015).

Because late relapse is extremely low, successful treatment is usually measured by achieving a SVR at any point of treatment (Smith-Palmer et al., 2015). Longterm follow-up studies have shown that achieving a SVR is associated with lower mortality rates and treatment costs with improvement of health related quality of life (Jafferbhoy et al., 2010; Larrey et al., 2014). Moreover, lowering the incidence of treatment emergent adverse events and shortening of the treatment course observed within the daclatasvir group in this study positively influenced the patients' adherence to treatment.

Although cirrhotic patients were not well represented in both included studies, Hezode et al. (2014) reported that cirrhotic patients treated with 20 and $60 \mathrm{mg}$ of daclatasvir achieved SVR rates of 62 and $63 \%$ respectively, in contrast to $38 \%$ achieved by patients treated with Peg-IFN/RBV alone (Hézode et al., 2014). Further evaluation of the efficacy of this regimen in cirrhotic population is needed.

Different genotypic subtypes may have different response rates to daclatasvir treatment. Genotype $4 \mathrm{a}$ and $4 \mathrm{~d}$ are the most prevalent phenotypes, especially in Egypt, Europe, and Saudi Arabia (Al Ashgar et al., 2013). 


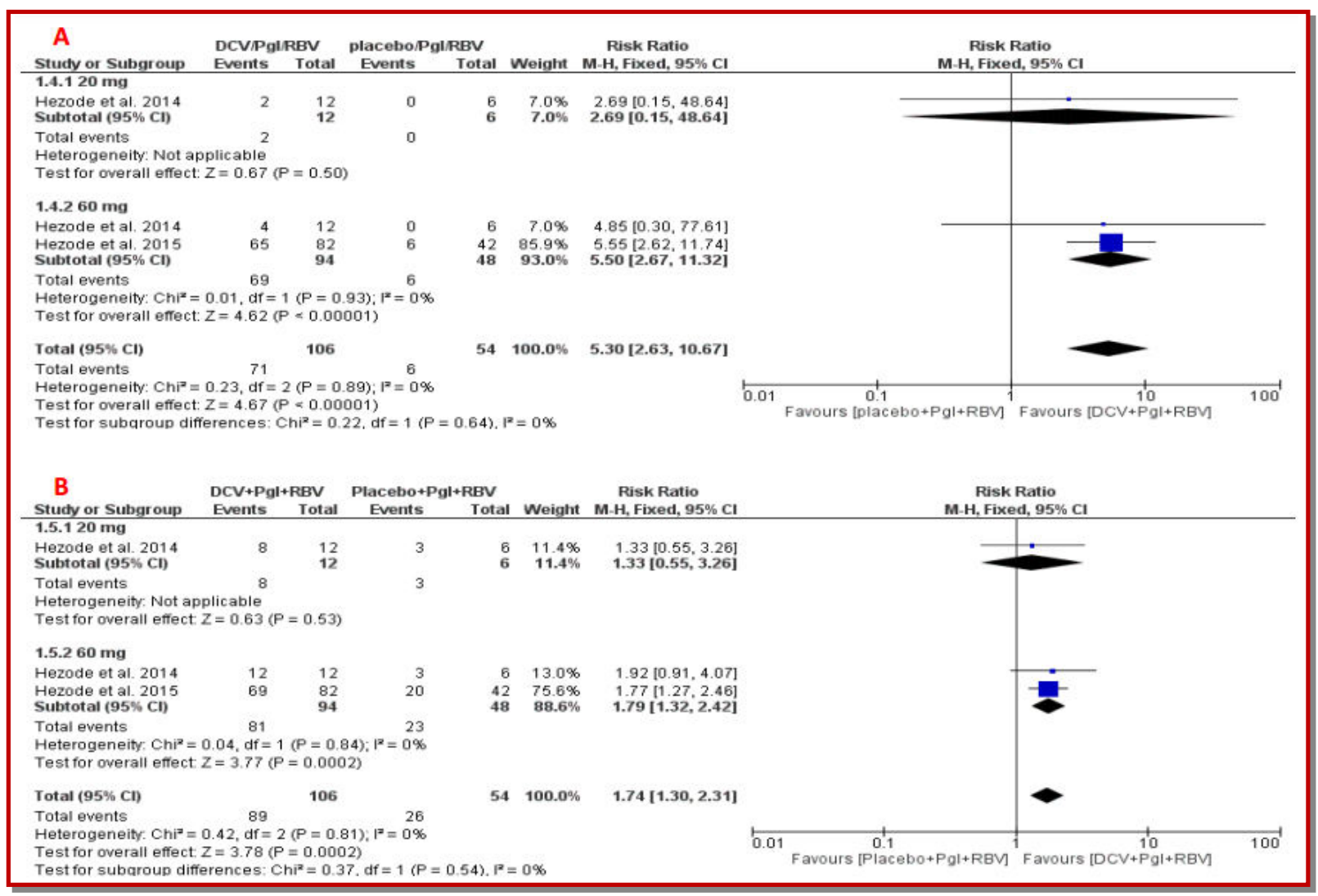

Figure 4: Forest plots comparing the dual and triple regimens in terms of extended rapid virologic response rate (A) and complete early virologic response rate (B)

Both subtypes were well represented in the included study by Hezode et al. (2015), which showed that the triple regimen achieved higher SVR rates in genotype $1 \mathrm{~b}$ and 4, compared to genotype 1a (Hézode et al., 2015). Further evaluation of the impact of different genotypic subtypes on virological response rates to the daclatasvir-containing regimen is required in larger clinical trials.

Few reports described that NS5A genetic polymorphisms can influence virological response to daclatasvir in HCV genotype 4 patients (Fridell et al., 2011; Gao et al., 2010; Hézode et al., 2014; Zhou et al., 2016). One hundred thirty four out of $229 \mathrm{HCV}$ genotype 4 patients had NS5A polymorphisms (Zhou et al., 2016). They found that the most common NS5A polymorphism was L30R substitution, which is estimated to decrease the response to daclatasvir by 10 folds, compared to patients without this polymorphism (Zhou et al., 2016). Hezode et al. (2014) reported that patients with CC IL28B genotype had a higher chance of achieving SVR, compared to those with a non-CC genotype, regardless of therapy (Hézode et al., 2014). Also, as shown by in vivo and in vitro studies, the combination of L30 polymorphism and IL28B non-CC genotype can significantly increase daclatasvir resistance (Wang et al., 2012; Wang et al., 2014).
Although safety outcomes of daclatasvir were not eligible for quantitative analysis, both included studies reported that adding daclatasvir to Peg-IFN/RBV did not increase the rate of adverse events, compared to the dual regimen. The most frequently reported adverse events in both regimens were headache, fatigue and nausea (Hézode et al., 2014; Hézode et al., 2015).

\section{Overall completeness of evidence}

Of the 154 patients included in this analysis, there were 39 discontinuations $(25.3 \%)$ in the two included trials (daclatasvir 23/106 and placebo 16/48). However, we believe this is unlikely to affect the analysis outcomes because the investigators of both studies analyzed their data in an intention to treat approach by considering all patients allocated to study arms, regardless of any discontinuation following randomization

\section{Strength points}

Both studies included in this analysis were of low risk of bias as indicated by Cochrane risk of bias assessment tool. We followed the PRISMA statement guidelines during preparation and reporting of this meta-analysis and conducted all steps in accordance to Cochrane handbook of systematic reviews of interventions. We also conducted a subgroup analysis to evaluate the effect of daclatasvir dose on the patients' response. 


\section{Limitations}

The relatively small number of available studies discussing our objective limits the generalizability of our findings. Both included studies enrolled only treatment naïve patients. Future studies should evaluate the efficacy of the same regimen in partial or null responders.

\section{Conclusion}

The present meta-analysis shows that the triple regimen of daclatasvir plus Peg-IFN/RBV achieved higher response and lower relapse rates than the dual regimen of Peg-IFN/RBV. Both daclatasvir doses (60 mg vs 20 $\mathrm{mg}$ ) achieved similarly moderate virological response rates. However, the current evidence is not sufficient and further randomized controlled trials are needed.

\section{Conflict of Interest}

All authors have completed the ICMJE uniform disclosure form and declare no support from any organization for the submitted work.

\section{References}

Al Ashgar HIA, Khan MQ, Al-Ahdal M, Thawadi SA, Helmy AS, Qahtani AA, Sanai FM. Hepatitis C genotype 4: Genotypic diversity, epidemiological profile, and clinical relevance of subtypes in Saudi Arabia. Saudi J Gastroenterol. 2013; 19: 28.

Armstrong GL, Wasley A, Simard EP, McQuillan GM, Kuhnert WL, Alter MJ. The prevalence of hepatitis $C$ virus infection in the United States, 1999 through 2002. Ann Intern Med. 2006; 144: 705-14.

Chan P, Tafoya E, Bifano M, Bertz R, Yin P, Hughes E, Ahmad A. Exposure-response analysis of daclatasvir in patients with genotype 1 chronic HCV infection: Dose selection for phase 3 clinical trials. Rev Antivir Ther Infect Dis. 2012; 6: 14

Cornberg M, Razavi HA, Alberti A, Bernasconi E, Buti M, Cooper C, Forns X. A systematic review of hepatitis C virus epidemiology in Europe, Canada and Israel. Liver Int. 2011; 31: $30-60$

Dore GJ, Lawitz E, Hézode C, Shafran SD, Ramji A, Tatum HA, Zaltron S. Daclatasvir plus peginterferon and ribavirin is non-inferior to peginterferon and ribavirin alone, and reduces the duration of treatment for $\mathrm{HCV}$ genotype 2 or 3 infection. Gastroenterology 2015; 148: 355-66.

Egger M, Smith GD, Schneider M, Minder C. Bias in metaanalysis detected by a simple, graphical test. BMJ. 1997; 315: $629-34$.

Everson GT, Sims KD, Rodriguez-Torres M, Hézode C, Lawitz $\mathrm{E}$, Bourlière $\mathrm{M}$, Tatum H. Efficacy of an interferon-and ribavirin-free regimen of daclatasvir, asunaprevir, and BMS791325 in treatment-naive patients with $\mathrm{HCV}$ genotype 1 infection. Gastroenterology 2014; 146: 420-29.

Fridell RA, Qiu D, Valera L, Wang C, Rose RE, Gao M. Distinct functions of NS5A in hepatitis C virus RNA replication uncovered by studies with the NS5A inhibitor BMS-790052. J Virol. 2011; 85: 7312-20.

Fridell RA, Wang C, Sun J, O'Boyle DR, Nower P, Valera L, Kienzle B. Genotypic and phenotypic analysis of variants resistant to hepatitis $\mathrm{C}$ virus nonstructural protein $5 \mathrm{~A}$ replication complex inhibitor BMS-790052 in Humans: In vitro and In vivo correlations. Hepatology 2011; 54: 1924-35.

Gao M, Nettles RE, Belema M, Snyder LB, Nguyen VN, Fridell $\mathrm{RA}$, Serrano $\mathrm{MH}, \mathrm{Wu}$, Langley DR, Jin, Sun H, O'Boyleli DR, Lemm JA, Wang C, Knipe JO, Chien C, Colonno RJ, Grasela DM, Meanwell NA, Hamann LG. Chemical genetics strategy identifies an HCV NS5A inhibitor with a potent clinical effect. Nature 2010; 465: 96-100.

Ghany MG, Strader DB, Thomas DL, Seeff LB. Diagnosis, management, and treatment of hepatitis C: An update. Hepatology 2009; 49: 1335-74.

Hanafiah KM, Groeger J, Flaxman AD, Wiersma ST. Global epidemiology of hepatitis $C$ virus infection: New estimates of age-specific antibody to HCV seroprevalence. Hepatology 2013; 57: 1333-42.

Hassanein T, Sims KD, Bennett M, Gitlin N, Lawitz E. A randomized trial of daclatasvir in combination with asunaprevir and beclabuvir in patients with chronic hepatitis $C$ virus genotype 4 infection. J Hepatol. 2015; 62: 1204-06.

Hézode C, Alric L, Brown A, Hassanein T, Rizzetto M, Buti M, Treitel M. Randomized controlled trial of the NS5A inhibitor daclatasvir plus peginterferon and ribavirin for $\mathrm{HCV}$ genotype-4 (COMMAND-4). Antivir Ther. 2015; 4.

Hézode C, Hirschfield GM, Ghesquiere W, Sievert W, Rodriguez-Torres M, Shafran SD, Esmat G, et al. Daclatasvir plus peginterferon alfa and ribavirin for treatment-naive chronic hepatitis $C$ genotype 1 or 4 infection: A randomised study. Gut 2014; 64: 948-56.

Jafferbhoy H, Gashau W, Dillon JF. Cost effectiveness and quality of life considerations in the treatment of hepatitis $\mathrm{C}$ infection. Clin Economics Outcomes Res. 2010; 2: 87.

Jensen D, Sherman KE, Hézode C, Pol S, Ledinghen V, De Tran A, Hughes E. Daclatasvir and asunaprevir plus peginterferon alfa and ribavirin in HCV. J Hepatol. 2015; 2: 18.

Kamal SM. Hepatitis C virus genotype 4 therapy: Progress and challenges. Liver Int. 2011; 31: 45-52.

Karoney MJ, Siika AM. Hepatitis C virus (HCV) infection in Africa: A review. Pan Afr Med J. 2013; 14.

Kumada H, Suzuki Y, Ikeda K, Toyota J, Karino Y, Chayama K, Takaguchi K. Daclatasvir plus asunaprevir for chronic HCV genotype $1 \mathrm{~b}$ infection. Hepatology 2014; 59: 2083-91.

Larrey D, Ripault MP, Pageaux GP. Patient adherence issues in the treatment of hepatitis C. Patient Prefer Adher. 2014; 8: 763.

Lawitz E, Mangia A, Wyles D, Rodriguez-Torres M, Hassanein T, Gordon SC, Reddy KR. Sofosbuvir for previously untreated chronic hepatitis C infection. N Engl J Med. 2013; 368: 1878-87.

Lee C, Ma H, Hang JQ, Leveque V, Sklan EH, Elazar M, Glenn 
protein. Virology 2011; 414: 10-18.

Lindsay KL. Therapy of hepatitis C: Overview. Hepatology 1997; 26.

Moher D. Preferred reporting items for systematic reviews and meta-analyses: the PRISMA statement. Ann Intern Med. 2009; 151: 264. e1000097.

Moreno C, Hezode C, Marcellin P, Bourgeois S, Francque S, Samuel D, Ouwerkerk-Mahadevan S. P1319 once-daily simeprevir (tmc435) with peginterferon/ribavirin in treatment-naive or treatment-experienced chronic HCV genotype 4-infected patients: Final results of a phase III trial. J Hepatol. 2014; 60: S535.

Negro F, Alberti A. The global health burden of hepatitis C virus infection. Liver Int. 2011; 31: 1-3.

Pawlotsky JM, Aghemo A, Back D. EASL recommendations on treatment of hepatitis C 2015. J Hepatol. 2015; 63, 199-236.

Qiu D, Lemm JA, O'boyle DR, Sun JH, Nower PT, Nguyen V, Ruediger E Hamann LG, Snyder LB, Deon DH, Ruediger E, Meanwell NA, Belema M, Gao M, Fridell RA. The effects of NS5A inhibitors on NS5A phosphorylation, polyprotein processing and localization. J Gen Virol. 2011; 92: 2502-11.

Smith DB, Bukh J, Kuiken C, Muerhoff AS, Rice CM, Stapleton JT, Simmonds P. Expanded classification of hepatitis $C$ virus into 7 genotypes and 67 subtypes: Updated criteria and genotype assignment web resource. Hepatology 2014; 59: 318 -27 .

Smith-Palmer J, Cerri K, Valentine W. Achieving sustained virologic response in hepatitis $\mathrm{C}$ : A systematic review of the clinical, economic and quality of life benefits. BMC Infect Dis. 2015; 15: 1.

Sulkowski MS, Gardiner DF, Rodriguez-Torres M, Reddy KR, Hassanein T, Jacobson I, Grasela DM. Daclatasvir plus sofosbuvir for previously treated or untreated chronic HCV infection. N Engl J Med. 2014; 370: 211-21.
Suzuki Y, Ikeda K, Suzuki F, Toyota J, Karino Y, Chayama K, $\mathrm{Hu} \mathrm{W}$. Dual oral therapy with daclatasvir and asunaprevir for patients with $\mathrm{HCV}$ genotype $1 \mathrm{~b}$ infection and limited treatment options. J Hepatol. 2013; 58: 655-62.

Swallow E, Song J, Yuan Y, Kalsekar A, Kelley C, Mu F, Signorovitch J. Daclatasvir + sofosbuvir versus standard of care for hepatitis $C$ genotype 3: A matching-adjusted indirect comparison. J Comp Eff Res. 2015.

Terrin N, Schmid CH, Lau J, Olkin I. Adjusting for publication bias in the presence of heterogeneity. Stats Med. 2003; 22: 2113-26.

Thompson AJ, Muir AJ, Sulkowski MS, Ge D, Fellay J, Shianna $\mathrm{KV}$, Esteban R. Interleukin-28B polymorphism improves viral kinetics and is the strongest pretreatment predictor of sustained virologic response in genotype 1 hepatitis $C$ virus. Gastroenterology 2010; 139: 120-29.

Wang C, Jia L, Huang H, Qiu D, Valera L, Huang X, Gao M. In vitro activity of BMS-790052 on hepatitis $C$ virus genotype 4 NS5A. Antimicrob Agents Chemother. 2012; 56: 1588-90.

Wang C, Jia L, O'Boyle DR, Sun JH, Rigat K, Valera L, Roberts $\mathrm{S}$. Comparison of daclatasvir resistance barriers on NS5A from hepatitis $C$ virus genotypes 1 to 6: Implications for cross-genotype activity. Antimicrob Agents Chemother. 2014; 58: 5155-63.

Yu J, Wang G, Sun L, Li X, Li S. Predictive value of rapid virological response and early virological response on sustained virological response in $\mathrm{HCV}$ patients treated with pegylated interferon a-2a and ribavirin. J Gastroenterol Hepatol. 2007; 22: 832-36.

Zhou N, Hernandez D, Ueland J, Yang X, Yu F, Sims K, McPhee F. NS5A sequence heterogeneity and mechanisms of daclatasvir resistance in hepatitis $C$ virus genotype 4 infection. J Infect Dis. 2016; 213: 206-15. 


\begin{tabular}{|c|c|c|}
\hline \multicolumn{3}{|l|}{ Hezode, 2014} \\
\hline Domain & Risk of Bias & Author judgment (quoting from the text) \\
\hline $\begin{array}{l}\text { Random sequence generation } \\
\text { (selection bias) }\end{array}$ & Low & $\begin{array}{l}\text { Quote: "phase2b study Using a randomized block design } \\
\text { stratified \& randomization ratio is } 2: 2: 1 \text { as follow daclatasvi- } \\
\text { r20mg, } 60 \mathrm{mg} \text {,placebo groups" } \\
\text { Comment: Probably done "patients were randomly allocated" }\end{array}$ \\
\hline $\begin{array}{l}\text { Concealment of allocation } \\
\text { (selection bias) }\end{array}$ & Low & $\begin{array}{l}\text { Quote:" using interactive voice response system" } \\
\text { Comment: Probably done "central allocation" }\end{array}$ \\
\hline $\begin{array}{l}\text { Blinding of participants } \\
\text { \&personnel (performance bias) }\end{array}$ & Low & $\begin{array}{l}\text { Quote: "double blind" } \\
\text { Patient \& study site were blinded to HCV-RNA value } \\
\text { \&patient randomization"" } \\
\text { Comment: Probably done }\end{array}$ \\
\hline $\begin{array}{l}\text { Blinding of outcome assessors } \\
\text { (detection bias) }\end{array}$ & Low & $\begin{array}{l}\text { Quote: "double blind" } \\
\text { Sponsor was blinded to treatment assignment"" } \\
\text { Comment: Probably done }\end{array}$ \\
\hline $\begin{array}{l}\text { Incomplete data reporting } \\
\text { (attrition bias) }\end{array}$ & Low & $\begin{array}{l}\text { Quote:" Modified intention to treat analysis done to all patient } \\
\text { " }\end{array}$ \\
\hline $\begin{array}{l}\text { Selective outcome reporting } \\
\text { (reporting bias) }\end{array}$ & Low & $\begin{array}{l}\text { The protocol is available \& all pre-specified outcomes have } \\
\text { been reported in pre-specified way }\end{array}$ \\
\hline others & Unclear & \\
\hline \multicolumn{3}{|l|}{ Hezode, 2015} \\
\hline Domain & Risk of Bias & Author judgment (quoting from the text) \\
\hline $\begin{array}{l}\text { Random sequence generation } \\
\text { (selection bias) }\end{array}$ & low & $\begin{array}{l}\text { Quote: " Multicenter phase } 3 \text { study, randomization using block } \\
\text { design 2:1 to DCV: placebo within each block, stratified" } \\
\text { Comment: Probably done "patients were randomly allocated }\end{array}$ \\
\hline $\begin{array}{l}\text { Concealment of allocation } \\
\text { (selection bias) }\end{array}$ & low & $\begin{array}{l}\text { Quote:" using validated centralized interactive voice response sys- } \\
\text { tem for randomization" } \\
\text { Comment: Probably done "central allocation }\end{array}$ \\
\hline $\begin{array}{l}\text { Blinding of participants } \\
\text { \&personnel } \\
\text { (performance bias) }\end{array}$ & low & $\begin{array}{l}\text { Quote :"Double blind( reported in protocol: blinded patient \& in- } \\
\text { vestigator)" } \\
\text { Comment: Probably done }\end{array}$ \\
\hline $\begin{array}{l}\text { Blinding of outcome assessors } \\
\text { (detection bias) }\end{array}$ & low & $\begin{array}{l}\text { Quote :"Double blind(regard protocol sponsor is blinded)" } \\
\text { Comment: Probably done }\end{array}$ \\
\hline $\begin{array}{l}\text { Incomplete data reporting } \\
\text { (attrition bias) }\end{array}$ & low & $\begin{array}{l}\text { Quote:" Modified intention to treat analysis done with patient with } \\
\text { missing HCV RNA at post treatment week } 12 \text { considered as fail- } \\
\text { ure" }\end{array}$ \\
\hline $\begin{array}{l}\text { Selective outcome reporting } \\
\text { (reporting bias) }\end{array}$ & low & $\begin{array}{l}\text { The protocol is available \& all pre-specified outcomes have been } \\
\text { reported in pre-specified way }\end{array}$ \\
\hline others & Unclear & $\begin{array}{l}\text {-Protocol deviation } \\
\text { One patient with GT1a infection was incorrectly enrolled in DCV } \\
\text { plus peg IFN/RBV group \&was included in the analysis due to the } \\
\text { pre-specified MITT analysis } \\
\text {-The limitation was a limited sample size }\end{array}$ \\
\hline
\end{tabular}

Supplementary data shows the results of risk of bias assessment for included studies 


\section{Your feedback about this paper}

1. Number of times you have read this paper 0

2. Quality of paper Click

3. Your comments

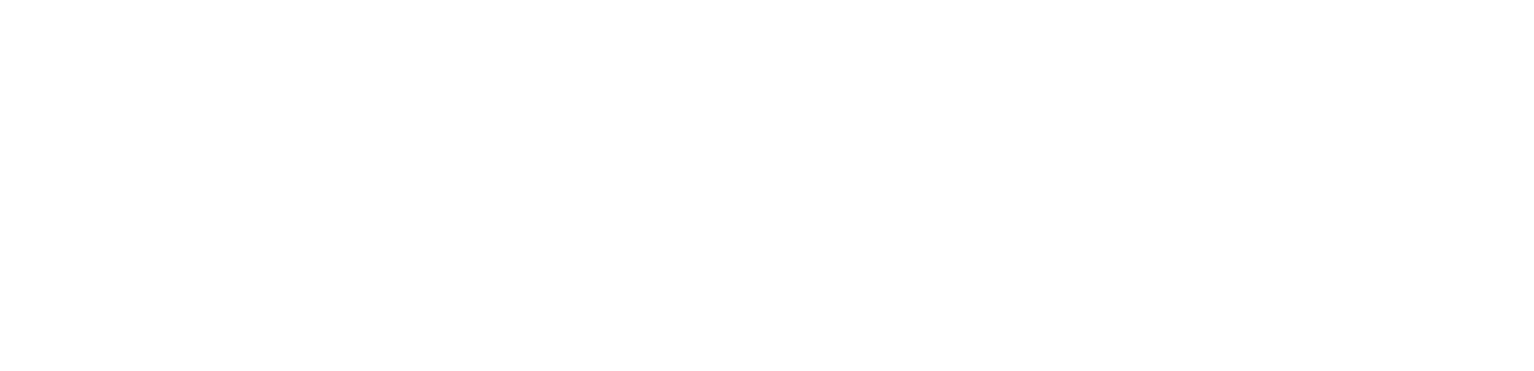

